Vol. 6, n² | 2002

Varia

\title{
Criminalized violence and the process of civilisation: a reappraisal
}

Gerd Schwerhoff

Translator. Lukas Hoffmann

\section{OpenEdition}

Journals

\section{Electronic version}

URL: https://journals.openedition.org/chs/418

DOI: $10.4000 /$ chs. 418

ISSN: 1663-4837

Publisher

Librairie Droz

\section{Printed version}

Date of publication: 1 December 2002

Number of pages: $103-126$

ISBN: 2-600-00812-8

ISSN: $1422-0857$

\section{Electronic reference}

Gerd Schwerhoff, "Criminalized violence and the process of civilisation: a reappraisal", Crime, Histoire \& Sociétés / Crime, History \& Societies [Online], Vol. 6, n² | 2002, Online since 25 February 2009, connection on 22 March 2022. URL: http://journals.openedition.org/chs/418 ; DOI: https://doi.org/ $10.4000 /$ chs. 418

This text was automatically generated on 22 March 2022.

(c) Droz 


\title{
Criminalized violence and the process of civilisation: a reappraisal ${ }^{1}$
}

\author{
Gerd Schwerhoff \\ Translation : Lukas Hoffmann
}

1 The history of crime deals mainly with deviancy and the violation of norms. Nevertheless, historians of crime try to study the social standard as well. While looking at deviancy, they hope to shed light on people's attitudes, for example, towards property, sexuality and morality or towards the authorities. However, the most intensively debated topic, it seems, has been for quite some time the issue of violence. We are confronted with 'violence' in the court records in a variety of facets: murder and manslaughter, bodily harm and robbery, infanticide and rape. The level of violent crime is viewed as a central indicator of the forms and functions of violence in social life. And with the help of criminal statistics, criminal historians try to measure the degree of violence in a given society.

2 For the last few years the homicide rate has been regarded as a quantifiable indicator of the degree of violence in a particular period. The homicide rate in present-day criminology is the rate which shows the annual average of deaths caused by physical violence in a population of 100,000 . Twenty years ago, scholars concerned with the history of crime adopted this measurement. In 1983, Lawrence Stone made the criminological analysis of T.R. Gurr, which had been published two years earlier, known to the community of historians. Gurr had summarised the results of fragmented studies on violent crimes in England and projected them on the time scale. Stone developed Gurr's analysis of trends even further and came to the frequently cited conclusion «that medieval English society was twice as violence-prone as early modern English society, and early modern English society at least five times more violence-prone than contemporary English society» ${ }^{2}$. So both argue that a clear, long-term decline of violence had taken place. Subsequently, a lively debate unfolded whose course cannot be repeated (in detail) here. Soon, this debate crossed over the borders of England and uncovered varied new empirical data and led to an exchange on the methodology and the theory of criminal history. 
3 In 1996 a programmatic anthology entitled The Civilization of Crime took stock of the developments in historical research on crime ${ }^{3}$. In the introduction, its editors stated that historians of criminality had been evading the most interesting challenges for a long time, namely international comparison and analysis of long-term developments. Recently, however, a surprising mutual agreement could be seen emerging in the field of criminalized personal violence which seemed to prove that interpersonal physical violence - violence exercised by the state was not explicitly mentioned here - had decreased from its level in the Middle Ages. All relevant authors agreed that «the decline in the level of interpersonal violence took place sometime between the $17^{\text {th }}$ and the $18^{\text {th }}$ century - a period marked by the rise of state control over the population, but a time considerably before the great wave of urban-industrial growth and expansion» ${ }^{4}$. Finally they concluded that, in connection with this empirical verification of a general trend, Norbert Elias' theory of civilisation, the central theses of which are widely accepted, had gained new credit among historians.

4 In 1939, Norbert Elias published his book, About the Process of Civilization ${ }^{5}$. In this major work, the German sociologist tried to trace the changes in human behaviour from the $12^{\text {th }}$ to the $18^{\text {th }}$ century. The analysis of table manners using guidebooks on moral discipline and handbooks on etiquette (Zucht- und Benimmbücher) as the primary sources is the main topic of his presentation. In this analysis, he describes how noseblowing and spitting were subjected to an increasingly restrictive canon of rules. But also other expressions of emotion were governed by a process of civilisation, as Elias explains in the last chapters of the first volume of his opus magnum: Apart from the sexual drive, it is above all with die Angriffslust (that is aggressiveness - in German, 'the lust for attacking someone') that he is concerned here ${ }^{6}$. According to his description, this drive was also subject to the fundamental historical trend from 'external constraint' to 'internal constraint', a shift of the governing of emotions from the outside to the inside of the person. Elias does not perceive this increasing internalisation of outer constraints as increasing individual autonomy, but conversely as the result of a transformation of social constraint into personal constraint. Other secular processes are intertwined with this development, for example the tendency for increased functional specialisation in the working process or the development of a state-monopoly of power.

5 After having been a long-time outsider to the scientific community, Elias has, since the 1970s, progressively won recognition as he author of an important and inspiring classic study. The renaissance of Elias' paradigm in historical research on criminality is due above all to Pieter Spierenburg. Bearing in mind Elias' theories and his own research on early modern Amsterdam, the Dutch historian elaborated his interpretations of homicide rates and further developed them in a creative manner. Recently has he summarised his point of view in this journal and answered the rhetorical question: «Violence and the Civilising Process: Does it work?» clearly with a 'yes'. As he sees it, his perspective is backed up by a phalanx of historians from the Anglo-Saxon world, whereas a number of historians in Continental Europe - among them Martin Dinges and myself - take a stand against the civilisation-theoretical interpretation ${ }^{7}$.

6 The description of the main lines is very simple. On the one hand, those sceptical of such a far-reaching interpretation of homicide rates and the critics of the Elias paradigm are not confined to Continental Europe. In a review of the anthrology just mentioned, the Dutch historian Herman Roodenburg remarks with surprise that - in 
contrast to what the emphatic introduction suggests - only two authors refer to Norbert Elias in detail (namely, apart from Eva Österberg, Spierenburg himself!) ${ }^{8}$. No one who has read Jim Sharpe's critical remarks in the debate with Stone about the value of homicide rates ${ }^{9}$ will be surprised to hear that Sharpe mentions Elias only in passing in his article. On the other hand, there are enough «Continental» voices who concede that homicide rates - with or without reference to Elias - are central to furthering knowledge about criminality in the past and who distinctly criticise any cultural objections ${ }^{10}$. Hence, the dispute cuts right through the international family of historians of crime. According to the protagonists of this dispute, the «civilisation of violence» theory seems to be favoured by the majority of historians.

7 The following considerations are aimed at questioning some of the central premises and conclusions of this approach. By no means is this meant to ignite a feud among the community of historians of crime, particularly as there is common agreement about many aspects of it. Nevertheless, Pieter Spierenburg rightly claimed that there should be not only an analysis of Elias' original paradigm, but also of its creative developments ${ }^{11}$. This is exactly what this article is all about. It focuses exclusively on the topic of 'physical violence' and not on other issues of Elias' work ${ }^{12}$. Likewise excluded from the following analysis is the criminality of the $19^{\text {th }}$ and $20^{\text {th }}$ centuries whose developments would make an article on their own. In regard to the empirical data used, I am going to deal with the findings of German historians since their work tends to be unduly neglected in the international debate. To integrate this research, heretofore inaccessible to those unfamiliar with the German language, into the discussions of the international research community could be a rewarding by-product of this article ${ }^{13}$.

\section{Homicide rates}

8 First, the empirical basis: «Was the long-term decline of violence, from the $14^{\text {th }}$ to the middle of the $20^{\text {th }}$ century, real?» ${ }^{14}$. In his most recent article, Spierenburg himself hardly discusses the data systematically, but deals with only some aspects of their interpretation. He summarily refers to Manuel Eisner's re-analysis of European criminal history research. Taking 60 research papers, the Swiss sociologist distilled 290 estimated homicide rates recorded in the pre-statistical period ${ }^{15}$. Neither a comprehensive list nor an analysis of these data can be presented here, nor is this necessary ${ }^{16}$. Nevertheless, we still have to deal with this source material. In doing so, we have to distinguish the late medieval period (from the $13^{\text {th }}$ to the $15^{\text {th }}$ century) and the early modern period (from the $16^{\text {th }}$ to the $18^{\text {th }}$ century).

9 Extremely high rates for homicide circulate for the $14^{\text {th }}$ century in particular: spectacular front-runners are, for example, the English university town of Oxford, in the period from 1342 to 1348 with a homicide rate of 110; or the metropolis of Florence, whose rate of 52 during the years from 1352 to 1355 is exceeded by a value of 68 in the period from 1382 to 1385 . Similarly high rates can be found in Central Europe during the same time: Freiburg i. Br., for instance, had a homicide rate of between 60 and 90 in the second half of the $14^{\text {th }}$ century; the Moravian town of Olmütz, a rate of 77 ; and Krakow one of $64^{17}$. In the basis of the autopsy reports, which are viewed as being especially reliable, Spierenburg worked out a homicide rate of 47 to 59 for Amsterdam during a few years of the $15^{\text {th }}$ century ${ }^{18}$. Significantly lower are the values for some 
towns in the south and south-east of Germany: For Basel, a rate between 25 and 30 was calculated for the period from 1376 to 1456; similar rates were reached for Regensburg (from 1324 to 1350: 25) and Eger (from 1310 to 1390: 30) ${ }^{19}$. But even lower figures are easily found, especially for the $15^{\text {th }}$ century. In his recent study of Constance from 1430 to 1472 , Peter Schuster finds 16 assaults and homicides between 1468 and 1472 and thus calculates an average rate of 6.2. In Cologne, the homicide rate had a value of 10 during the years from 1468 to 1481 , according to the Totenbuch, where deaths caused by violence were registered by the judge ${ }^{20}$. For Brussels, a comparable rate of 12 can be estimated in the $15^{\text {th }}$ century ${ }^{21}$. Finally, there are relatively low figures for the Hanseatic cities of Wismar (from 1343 to 1428: 15) and Stralsund (1310-1399: 9) ${ }^{22}$.

Table 1: Homicide rates in late medieval Europe (= number of deaths caused by violent acts per 100,000 inhabitants)

\begin{tabular}{|l|l|l|}
\hline Regensburg: & $1324-1350$ & 25 \\
\hline Nürnberg: & $14^{\text {th }}$ century (individual years) & $25-60$ \\
\hline Oxford: & $1342-1348$ & $90-120$ \\
\hline Freiburg i. Br.: & Second half of $14^{\text {th }}$ century & $>50$ \\
\hline Olmütz: & $1353-1389$ (individual years) & 77 \\
\hline Antwerpen: & $1356 / 7,1367 / 8,1372-87$ & 23 \\
\hline Florenz: & $1352-5$ & 152 \\
\hline \hline Krakau: & $1380-368$ & 10.7 \\
\hline Basel: & $1376-1456$ & $25-30$ \\
\hline Brüssel: & $1404-1499$ & 1 \\
\hline Köln: & $1468-1481$ & 64 \\
\hline
\end{tabular}

Sources: Krakau, Regensburg: Schüssler (1998, pp. 216ff); Nürnberg: Schüssler (1991) p. 122); Oxford: Hammer (1978, p. 11); Freiburg: Wettmann-Junblut (1997, p. 93); Olmütz: Schüssler (1994, p. 166); Antwerpen: Schüssler (1998, p. 218); Florenz: Becker (1976, p. 287); Basel: Simon-Muscheid (1991; pp. 30f); Brüssel: Vanhemelryck (1981, p. 105); Köln: Schwerhoff (1991, p. 282).

10 This gives us some figures to play with. The validity of the listed data is often highly questionable. First of all, they all rely on highly heterogeneous source materials: Achtregister (lists of escaped and proscribed suspects) are compared with indictments, lists of executed delinquents with entries in Wundenbüchern (records of violent acts) or court bills. It is evident that a different subset of criminalized violence is looked into with each of these partial data. Secondly, the judicial-normative basis in space and time is extremely variable. That there are no relevant sources for the late- $13^{\text {th }}$ century is only an indicator of their dependency on the respective norms. Originally, homicide was not a penalized crime. Until far into the early modern period, it was possible to 
regulate manslaughter by monetary compensation payable by the culprit to the victim's family ${ }^{23}$.

11 In many cases the sources are as heterogeneous as the categories for the various criminal acts. Did court officials register only mere (affective) homicides or did they also include (wilful) murders? Did accidents or deaths in the context of feud violence prior to the ages of larger conflicts and wars find their way into the statistics? And what about lethal violence in the context of robbery? ${ }^{24}$. Another central problem is calculating populations. Usually the number of inhabitants can be estimated only roughly, short-term demographic changes cannot be taken into consideration. As difficult as such an undertaking is for the early modern period, attempts to do the same for the Middle Ages border on a juggling act: Given, for example, in his classic analysis of $13^{\text {th }}$-century England, multiplies the number of Doomesday Books mentioned in the inventory lists of households from 1086 by five in order to arrive at the total population figure of that time and multiplies this again by 2.5 to trace back the assumed growth of the population over the 150 years in between ${ }^{25}$.

Most proponents of the hypothesis of a civilisation of crime saw these and other problems with the applied methods of quantification and did not hesitate to acknowledge the difficulties of any such calculations. However, they argued, one should not exaggerate historical scepticism. Eisner, for instance, countered the criticism with "the socio-scientific expectation that, with a sufficiently large number of analyses, the various sources of error would neutralise each other, at least to such an extent that the rough structure of secular trends becomes visible». In his view, there were no systematic errors in his sample ${ }^{26}$. Another strategy rests on the fragmentary nature of the existing sources which - in the view of some scholars - only supports the assumption that the resulting figures are trustworthy minimal figures. Would «more complete» source material not increase these figures for obvious reasons? Due to these considerations there is a certain tendency (explicit or implicit) among scholars to favour the highest figures as 'those closest to reality'. Even though Spierenburg himself denies, in his most recent article, that anybody would "advocate a method of always accepting the highest figures reported», he argued slightly differently in an earlier article: at least «court cases involving arrested killers» and «record listing all cases with identified killers (including fugitive suspects) should be taken into consideration only when they are relatively high ${ }^{27}$. Martin Schüssler, whose works form a central reference for recent studies, interprets his material similarly. In contrast to Spierenberg (!), he barely touches on preliminary methodological considerations. A critical evaluation of the source material, for example, is completely lacking. Thus, his quantitative analyses are highly questionable from a methodological standpoint. When he calculates a homicide rate of 25 from his Nuremberg source material, for example, but finds a value of 65 for the year 1392, then it is the latter which he views as being «the likelier one ${ }^{28}$. Furthermore, years for which there is no source material are excluded in Schüssler's interpretation due to the assumption that the data of these years had been poorly registered. Of course, this may be true. But it is also possible that there were no sanctions during those years or even no deaths to be registered at all. And he often applies the same method when reproducing the research results of fellow scholars ${ }^{29}$.

13 The projection of homicide rates is only one possible source for a systematic biasof the source material. Population figures, too, are traditionally over- rather than 
underestimated ${ }^{30}$. Furthermore, there are many other problems with the measurement of «the basic total figure for the local population». Apart from England, which is an early exception to the rule, we have figures only for medieval towns. Apparently this is the seed of a systematic bias. Thus Beattie's figures for the $17^{\text {th }}$ and $18^{\text {th }}$ centuries, for example, hint at a significantly higher homicide rate in the urban context (cf. table 2). Generally speaking, it is quite difficult to ascertain whether such discrepancies between town and countryside are rooted in the different behaviour of people living in rural areas compared to those living in towns or if there are institutional reasons for these discrepancies. The impact of urban courts went far beyond the town wall especially in the late medieval period. Neither did the culprit and the victim have to originate from the same area for which the respective judicial court was responsible, nor did the crime necessarily have to take place within the boundaries of the local jurisdiction. Only rarely do we learn something about such details as, for example, in the Nuremberg book of outlaws from the year 1392: here we read about a journeyman, who had been banished for the rest of his life, «that he had stabbed a woman, who later died at Bamberg, with a knife» ${ }^{31}$. It is into this context that I would like to put my remarks about the pseudo-objectivity of the measurement of «manslaughters per 100,000 inhabitants $\aleph^{32}$. In contrast to modern small-sized villages, medieval towns of only 5,000 inhabitants could already be focal points of violence as well as foci of jurisdiction. It remains debatable whether the projection of small basic units onto this modern measurement of a homicide rate is - in a statistical or a mathematical sense - validor not: Two manslaughters in a town of 10,000 people would already make a value of 20 .

What can these figures for the Middle Ages prove? One could interpret them as a trend curve which shows a dramatic climax in the $14^{\text {th }}$ century, in comparison to the previous $13^{\text {th }}$ century and the following $15^{\text {th }}$ century. Such an interpretation would be highly questionable because of the above problems with the analysis of the source material. But tailoring these data to fit Elias' paradigm is an equally shaky proposition. The calculation of homicide rates from the $13^{\text {th }}$ to the $15^{\text {th }}$ centuries is fraught with so many problems that a comparison between these figures or even the determination of a trend on this basis seems to be methodologically inadmissible ${ }^{33}$. No doubt, the level of violence was relatively high in the late Middle Ages. But that is all we can safely say for that period.

For the early modern times, things are different indeed. The number of sources is considerably higher and so is the density of the source material. However this does not mean that the quality of most of the data improves dramatically. Moreover, the number of relevant analyses is still limited. As far as France is concerned, Spierenburg rightly complains about the total absence of comparable data. There are no accountable analyses of serial sources covering a longer period of time for the German-speaking territories either. Fragmented figures, as those on $17^{\text {th }}$-century Frankfurt-am-Main, according to which the number of murders halved during that period and further declined in the $18^{\text {th }}$ century, are worth being mentioned explicitly since they are so much the exception to the rule ${ }^{34}$.

From the $15^{\text {th }}$ century onwards, though, there does exist a new type of sources in some regions and towns, namely the registers of official body inspections (Totenbeschau) in cases of sudden death. Such body inspections, as they had been carried out by the Coroner in England, have already been mentioned for Amsterdam and Cologne as examples of this type of source material. For the period prior to the $17^{\text {th }}$ century, there 
are unfortunately only summary calculations for the Dutch metropolis. According to these figures, the homicide rate was approximately 28 for the period from 1524 to 1565, and between 21.1 and 24.2 for the selected years of 1560, 1570, 1580 and $1590^{35}$. For Cologne, the data can be interpreted in more detail for the time between 1557 and 1620 . Unfortunately there are no records for the following years and decades (cf. table 2). Conversely, the practice of body inspections in Amsterdam did not resume until 1667, but for the ensuing period, long-term serial data can be listed. By far the most valuable set of data are still those figures presented by Cockburn in 1991 for the English county of Kent on the basis of coroner inquests which cover a period from 1560 well into early modern times ${ }^{36}$.

Table 2: Homicide rates in $16^{\text {th }}$ and early $17^{\text {th }}$ century (=number of deaths caused by violent acts, per 100,000 inhabitants)

\begin{tabular}{|l|l|l|}
\hline Kent & Köln & Amsterdam \\
\hline & $1557-63: 13.5$ & $1560-62: 73$ \\
\hline \hline $1561-81: 3.5$ & $1574-81: 14.5$ & $1566-67: 82$ \\
\hline & & $1571-73: 36$ \\
\hline & & $1577-80: 46$ \\
\hline $1582-01: 5.6$ & $1582-01: 9.1$ & \\
\hline & & $1585: 31$ \\
\hline $1602-21: 3.9$ & $1602-20: 7.7$ & \\
\hline
\end{tabular}

Sources: Cockburn (1991, p. 78); Schwerhoff (1991, p. 283); Blastenbrei (1995, p. 71)

Note: The data from Cologne are not mere random samples, as Schüssler (1998), p. 220, wrote; for this table, the data has been re-organised and newly calculated.

Table 3: Homicide rates in $17^{\text {th }}$ and $18^{\text {th }}$ century (=number of deaths caused by violent acts, per 100,000 inhabitants)

\begin{tabular}{|l|l|l|l|}
\hline Kent & \multicolumn{2}{|c|}{ Surrey } & Amsterdam \\
\hline & Urban & Rural & \\
\hline $1561-81: 3.5$ & & & \\
\hline $1582-01: 5.6$ & & & \\
\hline $1602-21: 3.9$ & & & \\
\hline $1622-41: 3.8$ & & & \\
\hline $1642-61: 3.7$ & & & \\
\hline
\end{tabular}




\begin{tabular}{|l|l|l|l|}
\hline $1662-81: 4.3$ & $1660-79: 8.1$ & 4.3 & $1667-1679: 3.5$ \\
\hline $1682-01: 3.6$ & $1680-99: 5.0$ & 4.7 & $1693-1709: 10.2$ \\
\hline $1702-21: 2.7$ & $1700-19: 3.9$ & 2.9 & $1710-1726: 8.3$ \\
\hline $1722-41: 1.6$ & $1720-39: 2.8$ & 2.4 & \\
\hline $1742-61: 2.0$ & $1740-59: 2.0$ & 1.6 & $1752-1767: 2.5$ \\
\hline $1762-81: 1.9$ & $1760-79: 1.7$ & 1.1 & $1768-1783: 3.8$ \\
\hline $1782-01: 1.8$ & $1780-02: 0.9$ & 0.9 & $1784-1799: 2.6$ \\
\hline $1802-21: 1.4$ & & & $1800-1816: 1.5$ \\
\hline $1822-41: 0.9$ & & & \\
\hline
\end{tabular}

Sources: Cockburn (1991, p. 78); Beattie (1986, p. 108); Spierenburg (1996, p. 83).

Though the data presented here show greater validity than those for the medieval period, considerable problems with their interpretation remain. Many questions have already been raised by James Cockburn, who - as Spierenburg rightly notes - tends to minimise the relevance of his data for an analysis of the development of violence or negates such a development altogether. Up to now his arguments have not been sufficiently discussed. Insufficiently reflected, for example, is the question of whether there is a connection between homicide rates and violent offences in general. Apart from some excursions in this direction, there is no appropriate basis in source material for quantifing physical injuries and other violent offences ${ }^{37}$. In order to compensate this lack, it is the explicit or implicit premise of the civilisation of violence thesis that homicides are a valid indicator of all forms of criminalized physical violence - if only because it is the only existing somewhat «hard» indicator left. In fact, such offences can be seen as an extreme pole of a continuum of unspectacular violent acts running from mere threats and quarrels to severe physical injury ${ }^{38}$. This does not mean, however, that there is a continuing stable relation between the two factors over a long period of time. Most of the people killed by violent acts in the early modern period died because of their injuries, due to blood loss or of infections, which they would have no doubt survived in the $20^{\text {th }}$ century. In a comparison which aims at encompassing several epochs, categories of modern criminal statistics such as «attempted murder» and «severe bodily injury» have to be added to the homicides. One could argue here that medicine had not progressed significantly until the $19^{\text {th }}$ century, but there are other relevant factors that need to be taken into consideration. The accessibility and the use of weapons, for example, seem to be of central importance - a point which is primarily responsible for the enormous differences in the violent death statistics between Europe and the US. Still, these figures would not make us view the United States as being less civilised. The majority of violent deaths in the $16^{\text {th }}$ and early $17^{\text {th }}$ centuries, according to James Cockburn's analysis for Kent, was caused by thrust weapons, whereas, from the $17^{\text {th }}$ century onwards, the proportion of firearms and other tools has grown continually ${ }^{39}$. Does this mean, then, that potential thrust weapons have increasingly 
disappeared from daily life? Or are they just no longer used to settle disputes? These questions illustrate the necessity of a qualitative analysis of individual violence in the cultural context, which will be dealt with in the third part of this article.

Despite the methodological reservations, historical research, especially that concerned with pre-modern times, is always faced with a difficult source basis, and it is legitimate to make the most of quantifying methods. Looking at both the data and the numerous scattered hints, the impression is substantiated that the level of violence decreases from the $16^{\text {th }}$ to the $18^{\text {th }}$ century. Pieter Spierenburg has the merit of having pointed out this trend. However I would like to qualify this immediately in two respects: First there is no evidence that this is a long-term process. All that can be proven somewhat empirically is merely the fact that there has been a change in the levels of violence within a period of time that can be limited to 200 or 300 years. By the middle of the $18^{\text {th }}$ century at the latest, the level of lethal violence seems to have levelled out at a comparatively low level in England and on the Continent ${ }^{40}$. This does not apply to all parts of Europe, though, not for example to the Mediterranean area, where a distinct culture of violence prevailed for a longer period of time ${ }^{41}$. And this brings us to my second qualification, which is concerned with the dramatic difference between the graphs for one individual territory as well as the discrepancies between the respective geographic areas of research. There is at least the same need for an explanation for those discrepancies as there is one for the overall trend. Thus, the county of Kent shows a low homicide rate for the $16^{\text {th }}$ century which is reached by Amsterdam only in the second half of the $18^{\text {th }}$ century. By comparison, the figures from Cologne are already significantly higher, but the rates calculated by Peter Blastenbrei for late $16^{\text {th }}$ century Rom seem to be exorbitant. The privileged observation of a unidirectional development seen through the glasses of the theory of civilisation tend to obscure such significant differences. Elias' paradigm is about to become Elias' bias - at least in the context of the debate about violence.

\section{The civilising process}

19 Here we have arrived at the second pole of the discussion, the theory of civilisation as such. Pieter Spierenburg pleads for theoretically oriented historical research. According to his approach, theory and empirical data should always relate to one another without the empirical data acting blindly or the theory drifting away into unfounded speculation ${ }^{42}$. In the main, I agree on this. However the procedure just outlined must not lead to insecure empirical data being backed by a problematic theory or vice versa, and central problems being thus obscured. This is exactly the case for the theory of civilisation, its fields of research and the discussion about violence in particular.

Surely some of the aspects brought forward by Spierenburg in the wake of Elias are basically not contentious. Hence the connection between the development and frequency of individual violence, on the one hand, and the development of a monopoly of power by the state, on the other hand, can hardly be dismissed. By the way, the terminology used by Elias here is less problematic than Spierenburg suggests. Elias talks about the "monopoly of power» clearly in the sense of a 'monopolisation of legitimate physical power' ${ }^{43}$. In doing so, he follows explicitly the language of Max Weber, who defined the state as a «political institution which can make use of the 
monopoly of legitimate physical constraint ${ }^{44}$. Elias talks uninhibitedly of a «monopoly of force ${ }^{45}$. Spierenburg's attempt to translate this into 'military monopoly' is too narrow, even though military and tax control indeed represent two important aspects of the monopoly of power, according to Elias. Another important aspect for the history of violence, which Spierenburg touches on only in passing in this context, is the development of criminal law by the state, with its severe punishments. In the course of this development an increase in the exercise of state power was seen. The frequency of executions and other bodily punishments increased ${ }^{46}$. From the standpoint of the theory of civilisation, the monopolisation of power by the state had two opposite consequences: On one side, there was a decrease in interpersonal violence, an intensified internal pressure exercised by the state on its subjects, and, on the other, there was an externalisation of power onto the intergovernmental level in the form of state-building wars ${ }^{47}$.

Our goal should now be to look in more detail at the connection between the development of state monopoly of power and the changein individual violence. In following Norbert Elias' theory of civilisation, however, Spierenburg takes exactly the opposite route. He refers to a historic «macro-narrative» which seems to make the empirical data explainable by a plain theoretical explanation. By fitting it into the occidental process of civilisation, he thus officially ordains a historical trend which makes a more detailed analysis seem superfluous. This model is, in the end, a reductionist view in which the frequency of violence is dependent on the degree of affect control. This affect control is again connected with a slowly increasing development of state monopoly of power and social interdependencies: «Thus, the long-term decline in homicide resulted from a taming of aggressive impulses in daily social intercourse, which in its turn was a function of the rise and growth in power of states in Europe $»^{48}$.

22 A number of objections to this simple reductionist model can be made. In my view, Elias' idea of violence and aggression seems problematic. He conceptualises them as if they were just there naturally, as a proposition of the human being, which can be socially integrated and abolished only secondarily. From this viewpoint, the changes in the forms of violence always represent the dependent variable, whereas the social conditions of society with their twisted structure and the expanding power of the state appear as anonymous figures responsible for that process. The state apparatus of repression thus forms a somewhat stable lid for the social pressure cooker, slowly reducing the inevitable eruptive outbreaks of passions while trying to prevent them altogether. That Elias viewed violence as a social habit that is learned like any other human behaviour, as Spierenburg writes, could be surmised from some of Elias theoretic statements. His empirical analysis of knightly violence in the Middle Ages tells a completely different story, though. It is in this naïve and prejudiced interpretation of the sources that the various points of criticism, which I will not repeat here, originate ${ }^{49}$.

By no means is this supposed to be a simple know-it-all criticism of the work of a classic whose core cannot be shaken by minor, almost inevitable corrections in detail. Like no other modern thinker in modern times, Elias related empirical data and theory to each other. He rejected programmatically Weber's idea of a construction of ideal-types, of models which can fathom reality by an abstract terminology. His process of civilisation aims at being both a theory of social processes and their empirical proof. This has far- 
reaching consequences. In Elias' work there is an unclear relation between empirical data and theoretical premises. The mention of evidence by the sources is suggestive and episodic. Hardly ever does he quote in a methodologically controlled and controllable way. Possible criticism of his analyses can thus be rejected on various levels again and again, depending on what is needed: empirical objections can be devalued by referring to the process of civilisation, criticism of the concept as such can be countered with facts. Thus, Elias' theory is immune to possible attempts at falsification. Spierenburg chooses a similar strategy when he says that the theory of civilisation is «based on observed past trends and has no room for evolution» in order to defy ideologically critical reservations ${ }^{50}$. Yet the theory is used again as a «seeing aid» in order to show that there was a measurably higher degree of violence in the late Middle Ages and that its gradual decline in the early modern times was part of a secular trend.In my opinion, the borderline between a precisely fitting alliance of empirical data and theory, on one side, and a circular reasoning, on the other, has been unduly crossed here.

Spierenburg advances many anti-critical arguments with which the older Norbert Elias impatiently confronted his critics time and again. He counters all criticism against the ideological character of his theory of civilisation, against its teleological, evolutionistic main feature, against the transfiguration of modern times and the distorted, cliched perception of the Middle Ages with conceptual remarks made by Elias: processes of civilisation had direction but they were blind, unintentional, unplanned processes; they had no beginning and no end, they went on irregularly and intermittently; there could be backdrops, periods of de-civilisation and, yes, these processes were even primarily reversible. But for judging the value of a theory correctly, some general conceptual remarks are of little help. Instead, their application in practice must be the main criteria. As inspiring as singular ideas of Elias may be, his whole model for the discussion about violence is restricting.

The continuous change in empirical data and theory can also be observed in the handling of the French model. To what extent the French way of civilisation can be viewed as the model case for a process of civilisation through the royal court or to what extent there are alternative ways of development remain an open question. Spierenburg advocates the latter point of view and explains that a refinement of habits at the court in no way necessarily goes hand in hand with a subduing of violence - after all, the royals were still wearing weapons at court. Their renunciation of violence was based on external constraints rather than on automatic self-constraint ${ }^{51}$. For one thing, Spierenburg is inconsistent with his teacher here: Elias explicitly emphasised that the "affect household of a human being" had to be viewed as a whole, that various "utterances of urges», such as hunger, sexual drive or the drive to attack, were inseparably intertwined. This quite mechanical connection once more casts a bright light on the questionability of Elias' drive theory. But the second part of the argument is much more important because it operates from a theoretical element which is again and again viewed as being central to the theory of civilisation: the transition from external constraints to self-constraint. Indeed, this is a very original and highly interesting figure of thought. But how is this development to be controlled empirically? In regard to table manners, Elias has put forward a number of sources which actually hint at an internalisation of certain modes of behaviour. But for the sphere of violence mere arbitrariness seems to govern any analysis. That there were mere external constraints curbing the exercise of violence in the Middle Ages seems to have been 
evident for the sociologist. By using the roughly outlined Dark Ages as a starting point, he was much better able to contrast the process of civilisation, which originated in the court. Violence in the Middle Ages is portrayed as being controlled externally, the avoidance of violence later on, however, was a successful form of self-constraint. There are no detectable criteria for this historic operationalization. Instead, an external constraint can be constructed again, if necessary, as Spierenburg's argumentation shows, in order to remove inconsistencies from Elias' paradigm. At other points of the controversy, the self-constraint argument is omitted completely. In the process of the devolution of the Soviet Union and during the formation of non-pacifistic islands within Western metropolises, there was «a weakening of the state monopoly» which then, of course, was accompanied with a rise in the homicide rate ${ }^{52}$. In these cases, a successful internalisation of drives cannot have taken place, otherwise the weakening of the state's monopole of power would hardly suffice to explain the new increase in the HR. It is generally questionable how the curbing of human affects in daily life, on one side, can go together with an increase of violence in wars and civil wars reaching as far as genocide in modern times, on the other- at least, if one represents the "drives» of a human being as a unit, which was what Elias postulated.

\section{Habits and meanings}

Apart from the macro-historical approach to interpersonal violence, with the help of homicide rates and the theory of civilisation, the micro-historical perspective mentioned at the beginning has been successfully established and has produced numerous studies on the phenomenology of everyday violence. These analyses revolve around "the twin themes of ritual and honour», as Spierenburg rightly notes. In his view, these were «the only serious objection» to an application of the theory of civilisation to violence ${ }^{53}$. Would the binding of an offender to an all-encompassing code of honour and the strict ritualization of most duels not implicitly mean a control of affects and thus the exact opposite of what violence is all about in the theory of civilisation - namely unrestrained violence? In his discussion of these topics, Spierenburg comes to the conclusion that the perspective of the theory of civilisation can be combined with the latest studies on honour and ritual. And he refers to his own attempts, his integration of cultural and statistical approaches to the analysis of homicide rates in Amsterdam.

Let us take a brief look at these attempts. The nucleus of this ideal-model of analysis is a system «of two related but distinct axes». The poles of the first axis are formed by «impulsive violence versus planned or 'rational' violence», those of the second by «ritual or expressive violence versus instrumental violence» ${ }^{54}$. His analysis of a sample from Amsterdam court cases (the body inspection records do not provide the contextual evidence needed for an adequate analysis) shows that impulsive violence was quite dominant up to around 1750, whereas its share declined sharply from the middle of the $18^{\text {th }}$ century onwards. With this finding, Spierenburg combines another observation, which is concerned with the victim-offender relation. Impulsive violence in the form of sudden outbreaks of aggression between strangers or companions was found primarily in alehouses and on the street. Since approximately 1720 , however, he notes an increase of intrafamilial violence in comparison to the violence against outsiders, «a shift from the killing of strangers to the killing of intimates» ${ }^{55}$. In 
addition, this intrafamilial violence was to be seen more and more as an expression of long-term tensions, for example between spouses, rather than as impulsive panic reactions.

Spierenburg's suggestion is undoubtedly the work of a pioneer. Without such attempts at categorization, a further-reaching analysis of violence will hardly be possible. What we need is a set of terminological instruments which give the seemingly amorphous phenomenon of violence a sharper profile. This two-axis model can hardly be the best solution though. Among other things, Eva Lacour, a psychologist dealing with history, criticised the comparison of impulsive and rationally planned violence as inadequate and proposed a three-dimensional analysis instead: motivation (angry or unplanned), form (ritual/wilful or uncontrolled) and planning (planned or unplanned) ${ }^{56}$. Both of these two works ${ }^{57}$ fail, however, with respect to a methodological problem: the idea of attributing single cases to the respective poles of the model can hardly be understood and where such a categorization is understandable it seems to me very problematic. Lacour, for example, works with a highly heterogeneous set of «types of offenders», to whose configuration the reasons for the conflict and the occasion of the conflict, the place of the crime, offender and victim are used arbitrarily to characterise the respective type. "Fight for property» is thus juxtaposed with "conflict of honour», «revenge» with «alehouse conflicts» ${ }^{58}$. In doing so, the author herself admits that many conflicts over property could have a strong aspect of honour, for example, or that many types of conflict could be understood as aggression out of revenge. Her method, which is to select the dominant motives in a single case, seems arbitrary and exemplifies the difficulties connected with a solid categorisation of acts of violence on various levels. To put a question mark behind some of her findings, which themselves seem to question usual commonplaces of research, is appropriate. Observations such as that violent conflicts were rarely preceded by threats, that conflicts happened quickly, directly and were uncontrolled become questionable when the high rate of insults $18.3 \%$ for the county of Virneburg, higher than all acts of violence taken together (13.4\%) - are excluded from the analysis of violence ${ }^{59}$. Because it is here that those interactions took place which could have led to physical violence as well, but which did not!

The debate about a sensible categorisation of acts of violence has thus just begun and it is highly welcome. It is therefore especially unfortunate that Spierenburg reads his observations as evidence for the theory of civilisation and thus jumps to conclusions where further questions would be more pertinent. In his point of view, impulsive and ritual violence are combined with a low level of affect control, whereas instrumental and rational violence can maintain their position in «civilised» forms of society. Here, too, violence is being conceptualised as if it was a problem of the human nature which needs to be socially restrained and abolished. From this viewpoint, the changes in forms of violence are always seen as dependent variables, whereas intertwined social relations and the growth of state power figure as anonymous causes. Not only is this way of reasoning conceptually questionable, but it remains also empirically doubtful, because - as we have seen - long-term trends are hard to detect. Instead we find a shift in the 'faces of violence', which furthermore is quite precisely localisable in time.

But Spierenburg objects to this micro-historical perspective that it «simply provides no alternative theory $»^{60}$. That is true, if one accredits a 'theory' only when it claims a universal applicability similar to that of the theory of civilisation. Historical macro- 
narratives and theoretical scripts of modernisation are not experiencing a boom at the moment; in this respect the theory of civilisation is more or less the last theoretical dinosaur of its kind. But giving up the idea of a general theory about the course of historical processes does not mean that we have to renounce a theory-oriented perspective of analysis. Instead of dealing at length with the sociologists' debate about violence I would like to look at this discussion only briefly. In his review of research on violence since 1997, the sociologist, Trutz von Trotha, complains about his colleagues' low productivity on violence. According to him, the mainstream of modern empirical research was in fact not sociology of violence but a sociology of the reasons for violence. The sociological theory as such, including the most frequently cited classics as Durkheim, Weber or Simmel, did not have much to offer in this respect. Elias, too, as one of the "essential reference points in the current theory of violence», was no exception: «In fact, the nucleus of Elias' study is not concerned with violence, but with forms and changes in the control of violence. [...] Violence as such instead is understood mostly as an unbridled "affect», as an impulse and as natural shamelessness about one's own body and that of the other». Trotha's own research project opts for the phenomenological tradition of sociology. He demands a «thick description» in the sense of Clifford Geertz, an antireductionist and process-oriented microscopic analysis of violence. By proceeding in such a way, the «Why?» would be replaced by questions of «What?» and «How?». Still, he argues that he would be able to find and name sociological basic terms with a high degree of universal applicability ${ }^{61}$.

The micro-historical analyses of the recent years have already started to tackle this programmatically postulated task of perceiving violence as «meaningful behaviour» ${ }^{62}$. The consequences of such an approach can only be dealt with only briefly here ${ }^{63}$. I will start by reconsidering the definition. This may sound strange at first, because physical violence can be defined quite clearly as «harm done to another person». Instead I would plead for widening the understanding of the term «bodily harm» for the purposes of historical analysis, which means in concrete terms that mere threatening gestures such as the drawing of knifes and also (or even in particular) «verbal violence» should be taken into consideration as well. Many researchers might view the abolishment of the clear-cut boundary of «physical violence» as being problematic, and especially in the English-speaking world this term may be regarded as being «confusing from a linguistic standpoint ${ }^{64}$. But it is no coincidence that early modern jurisdiction (which could indeed separate insultsfrom manslaughter) was familiar with the term iniuria realis - a category into which extremely brutal acts of violence were subsumed ${ }^{65}$.

This was undoubtedly a jurisdictional reflex to social practice. In daily life, insulting words often marked the beginning of a spiral of violence which could end with manslaughter. Insults harm one's honour, which was at least as important as the integrity of the body. Or perhaps it was even part of this bodily integrity: metaphorical speaking, this honour could be understood as something like a «second skin» which had to be defended against violent attacks as much as the biological skin.

The definition of violence is thus closely connected with the question of its outward social form and function. International research has provided us with a «thick description» of everyday violent behaviour in late medieval and early modern societies which shows many variations in detail, but matches in outline. The acts of violence committed mostly by male offenders followed a highly ritualised dramaturgy and can ideal-typically be described as a process of escalation, which could start with teasing 
and insults, progress to threatening gestures - such as the drawing of knives - and assault, and could culminate in serious injuries and manslaughter. The continuing escalation was not inevitable, there were a number of ways to de-escalate a tense situation. The argument is quite convincing that the drawing of knives marked a kind of deadlock and made an exit from this conflict possible for both parties without either of them losing face. Accordingly, the urge to defend one's own honour in the forum of a virtual public was the driving force behind the acts of violence. On these occasions honour functioned as a kind of homogenising code which standardized the heterogeneous interests and motives. In other words: no matter whether conflicts between neighbours, inheritance disputes or conflicts with fellow members of the guild were at stake, these conflicts have always been translated in a language of honour and have thus been made negotiable on some level or have otherwise been settled violently. Whether the protagonists fought with sharp words or sharp knives does not make a difference, generally speaking ${ }^{66}$.

Such an approach is clearly different from that of the perspective of the theory of civilisation. Physical violence is no longer conceptualised as a phenomenon which is socially unwelcome at any place and at any time; instead it becomes describable and interpretable in its social meaning. Taking the concept of social control as the analytical reference point, one could say: physical violence in early modern times was not only the object of this control, but its medium at the same time. In conflicts argued out violently there was always the fulfilling of social norms at stake as well; such conflicts can be understood as attempts to sanction breaks with the norm. Of course, these two dimensions - social control of violence and social control by violence entertain a strained relationship. The exercise of violence was sanctioned negatively both by the authorities and by society in the Middle Ages as well as in early modern times; to bring about peace, to keep and to re-establish it if necessary, was one of the most treasured values of these centuries. Hence many of the measures taken aimed at a reconciliation between the arguing parties or at a reconciliation of the offender with the human community and with God. Even the judicially sanctioned act of homicide at least if it presented itself as a situational and unplanned manslaughter - followed this logic of functioning and remained within the private sphere of the compensational system far into early modern times. Shameful punishments were suspended fairly often by acts of mercy. Throughout this whole period, the regular punishment for physical violence which did not have a lethal end remained the fine. Physical violence was not criminalized consistently in pre-modern times, a fact which can be explained by its aforementioned double-facetted character.

This approach goes together with categorisations only if these are not meant as a mere confirmation of a given theory. Of course, macro-historical factors can and must be included in a second step. For any study of the influence of demography, the levels of urbanization and economic development may not seem to be very fashionable, but they continue to be the necessary tools for the work of the historian. Particular attention must be paid to the state as a generator of norms, of criminal procedure and as an agent of sanction. It is important, however, to find the exact mechanisms at work by which state power influenced the frequency and the shape of violence. Was it really a systematic and intensified social control by the authorities that helped suppress violence? This «causal scheme taken from the theory of civilisation ..., which in its shortest forms says: more disciplining social control, hence more methodical selfcontrol, hence less individual violence» strikes even followers of a modernisation 
theoretical perspective as being far too simplistic ${ }^{67}$. A slightly different light is thrown on this connection by the paradigms of «judicial standardisation» and the "use of justice». The term «juridification» (Verrechtlichung), which was actually coined in the analysis of political protests in early modern times, emphasizes the systematic character of the extension of the judicial apparatus in the early modern period ${ }^{68}$. It did not focus on the suppression of violence, but on the extension of an attractive spectrum of alternatives to resolve conflicts in the form of a functioning justice system which could be used by a large number of people. In order to test this hypothesis, a more detailed analysis of the court records would be necessary. So far there have been only very few serial analyses for Germany; there is no evidence for an increase of interpersonal violencebetween men of the same social group at the lower courts of the Fürstbistum Osnabrück since the late $17^{\text {th }}$ century, but the number of economic conflicts between the representatives of various social groups - as, for example, between well-to-do peasants and day labourers - have predominated at this court ever since then ${ }^{69}$.

Such a model, according to which informal mechanisms of social control were replaced by formal mechanisms, seems to share the mechanistic character of the theory of civilisation. After all, such informal mechanisms of control still exist today, only - at least in western societies - violence no longer has a central place. That is why we need to focus more closely on the interplay between those two levels, formalised social control of the law and informal control agencies of society, and ask if and how this interplay has changed over time. It is here that the concept of «the use of justice» sets in, which looks at how the historical protagonists dealt with the old and the new institutions ${ }^{70}$. Studies show how the options of a potential user of these institutions varied and that the decision between violent do-it-yourself, extra-judicial settlement or a court settlement remained dependent on the context for a long time.

37 A different explanatory model, which aims at outlining the historical change in the forms of violence, has been proposed by Joachim Eibach. In his area of research, the imperial city of Frankfurt in the $18^{\text {th }}$ century, he detected a gradually growing social consent to resolve conflicts peacefully. As a possible cause for this development, he sees a process of modernisation towards a bourgeois society (Verbürgerlichung). The new forms of upper-class social and cultural life had an increasingly shaping influence on the behaviour of the lower classes of urban society. The new ideal of a distinguished morality and concentrated emotions had undermined the traditional, physically violent culture of quarrels ${ }^{71}$. Undoubtedly these observations are inspired by Elias, where a shaping influence is attributed to the higher classes of society, too. Spierenburg also talks about a pacification of the élites as a historical development noticeable throughout the early modern and modern period and about a trend which left violence at the margins of society. He illustrates this with a highly significant example, namely a comparison between the inner city of Amsterdam in 1700 and that of Philadelphia in $2000^{72}$. No doubt the contrast between the general acceptance of violence beyond class boundaries in early modern times and their limitation to certain no-go-areas of big American cities, where only outsiders and losers live, is striking ${ }^{73}$. But is it really always the upper classes and the elites that gradually refrain from violence in conflicts? The demonstration of virility and the exercise of violence were part of aristocratic behaviour well into the early modern period ${ }^{74}$. Also urban patricians did not follow this model. Neither in $15^{\text {th }}$-century Konstanz nor in $16^{\text {th }}$-century Augsburg did they attract attention by an ostensible restraint from violence - quite the contrary ${ }^{75}$. This is even 
more noticeable the higher one goes up the social scale because members of the elite were usually far more able to protect themselves from legal sanctions due to their powerful social standing. The absence of a bourgeois upper class, of merchants and rentiers in the criminal statistics may indeed be an indicator of the social distance of this group with regard to the culture of violence of craftsmen (including the established masters!). In Cologne, however, findings show a quite different pattern already for the $16^{\text {th }}$ century and thus well before the period of Verbürgerlichung in the $18^{\text {th }}$ century ${ }^{76}$. In a rural area of the $18^{\text {th }}$ century, though, Frank finds an outstanding degree of violence in the rural upper classes ${ }^{77}$. Further research on this topic is absolutely necessary. For example, the change in social codes and the position of violence within this context need to be analysed. Promising beginnings are shown by Yves Castan's analysis for southern France, in which he notes a shift from the old code of 'honneur' towards the new code of 'honnêteté'78. Equally important is the answer to the question of the extent to which religious movements and groups, especially the process of confessionalisation, would have to be included into such analysis ${ }^{79}$. Moreover, the decline of the culture of violent disputes among craftsmen and peasants needs further explanation. If our hypothesis that violence is a medium of social control is correct, then this social code must have fulfilled important functions which were not replaceable at the drop of a hat. Did social polarisation and pauperisation in rural areas lead to a basic change in the way people behaved in conflicts ${ }^{80}$ ? Are there signs of the norms mediated by the guilds, losing their binding power or losing their connection to honour and violence? Following Émile Durkheim, Michael Eisner has most recently argued that the process of individualisation was an important factor in the decline of violence, a process which was simultaneously marked by a liberalisation of the binding norms of honour and shame that had been central to all groups ${ }^{81}$. Even if one disagrees with his modernisation-theoretical perspective, one must concede that he has formulated a hypothesis which can be a starting point for further historical research.

The basic argument of this article can - like Spierenburg's - be summed up in a few sentences. The highly problematic homicide rate as a measurement is unable to certify a long-term trend of the internalisation of interpersonal violence from the Middle Ages to modern times. Perhaps the only provable fact is that there was a decline in that rate in early modern times, namely in the $17^{\text {th }}$ and $18^{\text {th }}$ centuries. As much as Elias' paradigm has provided us with an important impetus for our research, it can hardly be applied to finding an adequate answer to the question of what the reasons for that change really were. By taking violence only as a blind affect, which had to be controlled by external and internal constraints,this theory prevents us from gaining a deeper understanding of violence. In contrast to Elias' bias, a historical-anthropological perspective to violence aims at analysing violence also as a medium of social control, as a productive and meaningful force, and as a social code, without losing sight of the macro-historical processes of change. 


\section{BIBLIOGRAPHY}

Bahlcke, J., Strohmeyer, A. (Eds), Konfessionalisierung in Ostmitteleuropa. Wirkungen des religiösen Wandels im 16. und 17. Jahrhundert in Staat, Gesellschaft und Kultur, Stuttgart, Steiner, 1999.

Beattie, J. M., Crime and the Courts in England, 1660-1800, Oxford, Clarendon, 1986.

Becker, M. B., Changing patterns of violence and justice in fourteenth-and fifteenth century Florence, Comparative Studies in Society and History 1976, 18, pp. 281-296.

Behringer, W., Mörder, Diebe, Ehebrecher. Verbrechen und Strafen in Kurbayern vom 16. Bis 18. Jahrhundert, in Van Dülmen, R. (Ed.), Verbrechen, Strafen und soziale Kontrolle, Frankfurt am Main, Fischer, 1990, pp. 85-132.

Blastenbrei, P , Kriminalität in Rom 1560-1585, Tübingen, Niemeyer, 1995.

Blauert, A., Schwerhoff, G. (Eds.), Kriminalitätsgeschichte. Beiträge zur Sozial- und Kulturgeschichte der Vormoderne, Konstanz, UVK, 2000.

Cockburn, J. S., Patterns of violence in english society: Homicide in Kent 1560-1985, Past \& Present 1991, 130, pp. 70-106.

Dinges, M., Die Ehre als Thema der Stadtgeschichte. Eine Semantik im Übergang vom Acien Régime zur Moderne, Zeitschrift für historische Forschung 1989, 16, pp. 409-440.

Dinges, M., Der Maurermeister und der Finanzrichter. Ehre, Geld und soziale Kontrolle im Paris des 18. Jahrhunderts, Göttingen, Vandenhoeck \& Ruprecht, 1994.

Dinges, M., Formenwandel der Gewalt in der Neuzeit. Zur Kritik der Zivilisationstheorie von Norbert Elias, in Sieferle, R. P., Breuninger, H. (Eds.), Kulturen der Gewalt. Ritualisierung und Symbolisierung von Gewalt in der Geschichte, Frankfurt/M., Campus, 1998, pp. 171-194.

Dinges, M., Justiznutzung als soziale Kontrolle in der Frühen Neuzeit, in Blauert, A., Schwerhoff, G. (Eds.), Kriminalitätsgeschichte. Beiträge zur Sozial- und Kulturgeschichte der Vormoderne, Konstanz, UVK, 2000, pp. 503-544.

Eibach, J., Städtische Gewaltkriminalität im Ancien Régime. Frankfurt am Main im europäischen Kontext, Zeitschrift für Historische Forschung 1998, 25, pp. 359-382.

Eisner, M., Individuelle Gewalt und Modernisierung in Europa, 1200-2000, in Albrecht, G., Backes, O., Kühnel, W. (Eds.), Gewaltkriminalität zwischen Mythos und Realität, Frankfurt/Main, Suhrkamp, 2001a, pp. 71-100.

Eisner, M., Modernization, self-control and lethal violence. The long-term dynamics of european homicide rates in theoretical perspective, The British Journal of Criminology 2001b, 41, pp. 618-638.

Elias, N., Über den Prozess der Zivilisation. Soziogenetische und psychogenetische Untersuchungen, 2 vol. (Gesammelte Schriften Bd. 3), Frankfurt/M., Suhrkamp, 1997.

Evans, R. J., Rituals of Retribution. Capital Punishment in Germany, 1600-1987, Oxford, Oxford Univ. Press, 1996.

Frank, M., Dörfliche Gesellschaft und Kriminalität. Das Fallbeispiel Lippe 1650-1800, Paderborn, Schöningh, 1995. 
Frank, M., Ehre und Gewalt im Dorf der Frühen Neuzeit. Das Beispiel Heiden (Grafschaft Lippe) im 17. u. 18. Jahrhundert, in Schreiner, K., Schwerhoff, G. (Eds.): Verletzte Ehre. Ehrkonflikte in Gesellschaften des Mittelalters und der Frühen Neuzeit, Köln, Böhlau, 1995a, pp. 320-338.

Fuchs, R.-P., Um die Ehre. Westfälische Beleidigungsprozesse vor dem Reichskammergericht 1525-1805, Paderborn, Schöningh, 1999.

Given, J. B., Society an Homicide in Thirteenth-Century England, Stanford, Stanford University Press, 1977.

Häberlein, M., Tod auf der Herrentrinkstube. Ehre und Gewalt in der Augsburger Führungsschicht (1500-1620), in Backmann, S. et al. (Eds.): Ehrkonzepte in der Frühen Neuzeit. Identitäten und Abgrenzungen, Berlin, Akademie, 1998, pp. 148-169.

Häberlein, M. (Ed.), Devianz, Widerstand und Herrschaftspraxis in der Vormoderne. Studien zu Konflikten im südwestdeutschen Raum (15.-18. Jh.), Konstanz, UVK, 1999.

Hammer Jr., C. I.: Patterns of homicide in a medieval university town: Fourteenth-century Oxford, Past \& Present, 1978, 78, pp. 3-23.

Isenmann, E., Die deutsche Stadt des Spätmittelalters. Stadtgestalt, Recht, Stadtregiment, Kirche, Gesellschaft, Wirtschaft, Stuttgart, Ulmer,1988.

Johnson, E. A., Monkkonen, E. H. (Eds.), The Civilization of Crime. Violence in Town and Country since the Middle Ages, Urbana and Chicago, University of Illinois Press, 1996.

Klein, G., Liebsch, K. (Eds.), Zivilisierung des weiblichen Ich, Frankfurt/M., Suhrkamp, 1997.

Kolmer, L., Gewalttätige Öffentlichkeit und öffentliche Gewalt. Zur städtischen Kriminalität im späten Mittelalter, Zeitschrift für Rechtsgeschichte Germanistische Abteilung, 1997, 114, pp. 261-295.

Kottmann, P., Gogerichte in der Agrargesellschaft des Hochstifts Osnabrück (1500-1800), Historische Mitteilungen,1998, 11, pp. 1-22.

Lacour, E., Schlägereyen und Unglücksfälle. Zur Historischen Psychologie und Typologie von Gewalt in der frühneuzeitlichen Eifel, Egelsbach, Hänsel-Hohenhausen, 2000.

Lacour, E., Faces of violence revisited. A typology of violence in early modern rural Germany, Journal of Social History, 2001, 35, pp. 649-668.

Lindström, D., Crime and control in the capital: Stockholm 1475-1625, in Österberg, E., Lindström, D., Crime and Social Control in Medieval and Early Modern Swedish Towns, Stockholm, Almqvist \& Wiksell, 1988, pp. 67-140.

Pröve, R., Gewalt und Herrschaft in der Frühen Neuzeit. Formen und Formenwandel der Gewalt, Zeitschrift für Geschichtswissenschaft, 1999, 47, pp. 792-806.

Rehberg, K.-S. (Ed.), Norbert Elias und die Menschenwissenschaften. Studien zur Entstehung und Wirkungsgeschichte seines Werkes, Frankfurt/M., Suhrkamp, 1996.

Rousseaux, X., Frome case to crime. Homicide regulation in medieval and modern Europe, in Willoweit, D. (Ed.), Die Entstehung des öffentlichen Strafrechts. Bestandsaufnahme eines europäischen Forschungsproblems, Köln, Böhlau, 1999, pp. 143-175.

Rummel, W., Verletzung von Körper, Ehre und Eigentum. Varianten im Umgang mit Gewalt in Dörfern des 17. Jahrhunderts, in Blauert, A., Schwerhoff, G. (Eds.), Mit den Waffen der Justiz. Zur Kriminalitätsgeschichte des späten Mittelalters und der Frühen Neuzeit, Frankfurt/M., Fischer, 1993, pp. 86-114. 
Schindler, N., Habitus und Herrschaft. Zum Wandel aristokratischer Herrschaftspraxis im 16. Jahrhundert, in Schindler, N., Widerspenstige Leute. Studien zur Volkskultur in der Frühen Neuzeit, Frankfurt/M., Fischer, 1992, pp. 78-120.

Schröter, M., Erfahrungen mit Norbert Elias, Frankfurt/M., Suhrkamp, 1997.

Schultheiss, W. (Ed.), Die Achts,- Verbots- und Fehdebücher Nürnbergs von 1285-1400, Nürnberg, Selbstverlag, 1960 .

Schüssler, M., Statistische Untersuchung des Verbrechens in Nürnberg im Zeitraum von 1285 bis 1400, Zeitschrift für Rechtsgeschichte Germanistische Abteilung,1991, 108, pp. 117-193.

Schüssler, M., Verbrechen im spätmittelalterlichen Olmütz. Statistische Untersuchung der Kriminalität im Osten des Heiligen Römischen Reiches, Zeitschrift für Rechtsgeschichte Germanistische Abteilung 1994, 111, pp. 148-271.

Schüssler, M., Verbrechen in Krakau (1361-1405) und seiner Beistadt Kasimir (1370-1402), Zeitschrift für Rechtsgeschichte Germanistische Abteilung 1998, 115, pp. 198-338.

Schulze, W. (Ed.), Europäische Bauernrevolten der frühen Neuzeit, Frankfurt/M., Suhrkamp, 1982.

Schulze, W. (Ed.), Aufstände, Revolten und Prozesse. Beiträge zu bäuerlichen Widerstandsbewegungen im frühneuzeitlichen Europa, Stuttgart, Klett-Cotta, 1983.

Schuster, P., Eine Stadt vor Gericht. Recht und Alltag im spätmittelalterlichen Konstanz, Paderborn, Schöningh, 2000.

Schuster, P., Richter ihrer selbst? Delinquenz gesellschaftlicher Oberschichten in der spätmittelalterlichen Stadt, in Blauert, A., Schwerhoff, G. (Eds.), Kriminalitätsgeschichte. Beiträge zur Sozial- und Kulturgeschichte der Vormoderne, Konstanz, UVK, 2000, pp. 359-378.

Schwerhoff, G., Köln im Kreuzverhör. Kriminalität, Herrschaft und Gesellschaft in einer frühneuzeitlichen Stadt, Bonn/Berlin, Bouvier, 1991.

Schwerhoff G., Falsches Spiel. Zur kriminalhistorischen Auswertung der spätmittelalterlichen Nürnberger Achtbücher, Mitteilungen des Vereins für die Geschichte der Stadt Nürnberg,1995, 82, pp. 23-35.

Schwerhoff G., Zivilisationsprozess und Geschichtswissenschaft. Norbert Elias' Forschungsparadigma in historischer Perspektive, Historische Zeitschrift 1998, 266, pp. 561-605.

Schwerhoff, G., La storia della criminalità nel tardo medioevo e nella prima età moderna. Il 'ritardo' di un settore della ricerca tedesca, Annali dell'Istituto storico italo-germanico in Trento $1998 \mathrm{~b}$ [erschienen 1999], 24, pp. 573-630.

Schwerhoff, G.: Aktenkundig und gerichtsnotorisch. Einführung in die historische Kriminalitätsforschung, Tübingen, edition diskord, 1999.

Schwerhoff, G., Insel des Friedens oder Brennpunkt der Gewalt? Die Reichsstadt Köln ca. 1470-1620, in Dinges, M., Sack, F. (Eds.), Unsichere Grossstädte? Vom Mittelalter bis zur Postmoderne, Konstanz, UVK, 2000, pp. 139-156.

Schwerhoff, G., Social Control of Violence - Violence as Social Control: The Case of Early Modern Germany, in Spierenburg P. (Ed.), Handbook of Social Control (2003, forthcoming).

Sharpe, J. A., Crime in England: Long-term trends and the problem of modernisation in Johnson, E.A., Monkkonen, E.H. (Eds), The Civilization of Crime. Violence in Town and Country since the Middle Ages, Urbana and Chicago, University of Illinois Press, 1996, pp. 17-34. 
Simon-Muscheid, K., Gewalt und Ehre im spätmittelalterlichen Handwerk am Beispiel Basels, Zeitschrift für Historische Forschung, 1991, 18, pp. 1-31.

Spierenburg, P., Faces of violence. Homicide trends and cultural meanings: Amsterdam 1431-1816, Journal of Social History, 1994, 27, pp. 701-716.

Spierenburg, P., Long-term trends in homicide: Theoretical reflections and Dutch evidence, fifteenth to twentieth centuries, in Johnson, E.A., Monkkonen, E.H. (Eds), The Civilization of Crime. Violence in Town and Country since the Middle Ages, Urbana and Chicago, University of Illinois Press, 1996, pp. 63-105.

Spierenburg, P., How violent were women? Court cases in Amsterdam, 1650-1810, Crime, Histoire et Sociétés, 1997, 1, pp. 9-28.

Spierenburg, P., Violence and the civilizing process: Does it work? Crime, Histoire et Sociétés, 2001, 5, 2, pp. 87-105.

Stone, L., Interpersonal violence in english society, 1300-1980, Past \& Present,1983, 101, pp. 22-33.

Trotha, T. von (Ed.), Soziologie der Gewalt, Opladen, Westdeutscher Verlag, 1997.

Vanhemelryck, F., De criminaliteit in de ammanie van Brussel van de late middeleeuwen tot het einde van het ancien regime (1404-1789), Bruxelles, Koninklijke Acad. voor Wetenschappen, 1981.

Walz, R., Agonale Kommunikation im Dorf der Frühen Neuzeit, Westfälische Forschungen, 1992, 42, pp. 215-251.

Weber, M., Wirtschaft und Gesellschaft. Grundriss der verstehenden Soziologie, 5., revidierte Auflage, ed. Winckelmann, J., Tübingen, Mohr, 1980.

Wettmann-Jungblut, P., Penal law and criminality in Southwestern Germany: Forms, patterns and developments 1200-1800, in Rousseaux, X., Levy, R. (Eds.): Le pénal dans tous ses États. Justice, États et Sociétés en Europe (XII ${ }^{e}-X^{e}$ siècles), Bruxelles, Facultés universitaires Saint-Louis, 1997, pp. 25-46.

Wettmann-Jungblut, P., Der nächste Weg zum Galgen? Studien zur Eigentumskriminalität in Südwestdeutschland 1550-1850, Diss. masch. Saarbrücken,1997 (to be published 2002).

\section{NOTES}

1. A preliminary version of this paper was read at the conference «Gewalt. Wahrnehmung und Regulierung von Gewalt in der Vormoderne», organized by Neithard Bulst and Peter Schuster in Bielefeld at the Zentrum für Interdisziplinäre Forschung, $2^{\text {th }-} 29^{\text {th }}$ November 1998 . The author is currently Professor of Early Modern History at the Technical University of Dresden. Besides criminal history, his main research interests are the history of early modern religion and the history of public spheres.

2. Stone (1983, p. 32).

3. Besides, «Violence in Town and Country since the Middle Ages» is the subtitle of this anthology - the topic of the discussion was not crime per se, but violence. Hence, according to the title, the confusion between violence and criminality, of which Spierenburg (2002, p. 95), accuses Claude Gauvard, is also prevalent among the editors of this anthology!

4. Johnson, Monkkonen (1996, p. 6f). At another point, the second half of the $18^{\text {th }}$ century is said to have been the decisive period (8).

5. Compare Elias (1997) for an annotated new edition which also includes variations from the 1982 English translation, authorised by Elias himself; on the reception of his works, see the essays in Rehberg (1996) and Klein, Liebsch (1997). 
6. Elias (1997, pp. 365ff.).

7. Dinges (1994, pp. 328ff.; 1998); Schwerhoff (1998, 1999).

8. Crime, Histoire et Société 2000, 4, 1, pp. 135-137.

9. Sharpe (1996, p. 30); cf. his 'observations' in Past and Present 108 (1985), pp. 206-215.

10. Cf. Rousseaux (1999, p.145); Eisner (2001a, b); Lacour (2000, 2001).

11. This indeed is the actual focus of my previous analysis of the theory of civilisation.

12. So far, the debate has focused on the topic area of «shame and embarrassment». A discussion would have to start from Schröter's (1997) further considerations.

13. Compare Schwerhoff (1998b) or my essay in Blauert, Schwerhoff (2000, pp. 21-67).

14. Spierenburg (2002, p. 91).

15. I am most grateful to Manuel Eisner who kindly provided me with a version of his paper before it was published (Eisner, 2001a; compare also Eisner, 2001b).

16. All following figures presented without an individual reference are taken either from the list by Schüssler (1998, pp. 218ff.) or from the tables by Rousseaux (1999, pp. 159ff.) respectively.

17. Wettmann-Jungblut (1997, p. 38); Schüssler (1994, pp. 166f.); Schüssler (1998, pp. 216f.).

18. Spierenburg (1996, p. 80).

19. Schüssler (1998, pp. 222f.); also Simon-Muscheid (1991, pp. 30f.) and Kolmer (1997, p. 276).

20. Schuster (2000b, p. 89f.); Schwerhoff (1991, pp. 282-284).

21. Compare Rousseaux (1999, p. 161) - he adds up methodologically correctly the figures presented by Vanhemelryck (1981, pp. 90-105), whereas Schüssler (1998, p. 218) wrongly states a very low value of 41 'murders'.

22. Schüssler (1998, p. 219).

23. For the development of homicide from case to crime, see Rousseaux (1999).

24. Lindström (1988, p. 92). Another, banal aspect of the categorization problem is the question of what or who is counted respectively: the dead, the deeds or the killers, compare SimonMuscheid (1991, p. 30) where 45 persons had been convicted for 30 cases of manslaughter.

25. Given (1977, p. 30f.).

26. Eisner (2001a, p. 74).

27. Spierenburg (2001, p. 91; 1996, p. 79).

28. Schüssler (1991, p. 122). As a critique, compare Schwerhoff (1995).

29. His representation of my findings for Cologne is visually distorting in that he takes individual years with maximum values only. Hence the homicide rate of 10 which I estimated is doubled, compare Schüssler (1998, p. 220). Typically enough too Spierenburg (1996, p. 66) presents my figures as «minimum rates».

30. Isenmann (1988).

31. Schultheiß (1961) no. 1008, 127.

32. Schwerhoff (1991, p. 286).

33. Even Manuel Eisner as a follower of the hypothesis of a long-term decline of violence concedes that «due to the problems with the data one should not make too far-reaching conclusions» Eisner (2001a, p. 84).

34. According to Eibach (1998, p. 387) there were 31 convicted offences of homicide between 1562 and 1594, whereas only 15 in the period from 1661 to 1694 and less than 10 of such convictions during the periods from 1741 to 1773 and from 1774 to 1805 respectively. Wettmann-Jungblut (1997) notes still 7 cases of murder or manslaughter for the small Benedictine convent of St. Blasien with approximately 3,000 inhabitants, whereas no such case was found for the 20 years between 1753 and 1773 .

35. Spierenburg (1996, pp. 80f.).

36. For a tabular presentation of the data, it is more advisable to have separate tables for the late $16^{\text {th }}$ and early $17^{\text {th }}$ century and for the late $17^{\text {th }}$ and the $18^{\text {th }}$ century. Additionally, contrasting figures have been added on the one hand for Rom in the late $16^{\text {th }}$ century as a rare case of very 
dense material and on the other hand - rather as a supplement- the well-known data by Beattie which is based on «softer» source material, the homicide indictments.

37. Compare, for example, Lacour (2000, pp. 88ff.).

38. Spierenburg (1996, p. 74).

39. Cockburn (1991, pp. 79ff.).

40. Compare similarly Eisner (2001 a, b).

41. Compare Blasenbrei (1995); Eisner tries to distinguish the development of violence in the various European areas and concludes that the pioneer states of the process of modernization England and Holland were those in which the violence rates declined first. That this differentiation is empirically provable seems - apart from the obvious north-south divide, though - questionable to me due to the data basis.

42. Spierenburg (1996, p. 67).

43. Elias (1997, pp. 151ff., pp. 331ff.). For a general discussion on the terminological specification of «power» and «violence», see Pröve (1999).

44. Weber (1980, p. 29).

45. Elias (1997, p. 332); compare the English text p. 538.

46. For a comparison of the frequency and development of death penalties in early modern Germany, for example: Behringer (1990, p. 468); and more recently Evans (1996).

47. Pröve (1999, p. 803); cf. Spierenburg (2001, p. 97).

48. Spierenburg (1994, p. 702).

49. Schwerhoff (1998a, p. $576 \mathrm{ff}$.).

50. Spierenburg (2001, p. 100).

51. Spierenburg (2001, p. 99).

52. Spierenburg (2001, p. 101f.).

53. Spierenburg (2001, p. 94ff.). It should be aknowledged explicitely in this context that Spierenburg himself has made important contributions to the phenomenology of violence.

54. Spierenburg (1994, p. 704; 1996, p. 70).

55. Spierenburg (1996, p. 94).

56. Lacour (2000, pp. 182ff.; 2001, pp. 651f.). Incidentally, Lacour notes «only a few major changes» in the profile of violence for her rural area of research in West Germany between the $16^{\text {th }}$ and the $18^{\text {th }}$ century - an increase in violence within the family being on of them.

57. For a detailed comparison, see Schwerhoff (2003).

58. Lacour (2000, pp. 111ff.; 2001, p. 659).

59. Lacour (2000, pp. 89, 171ff.).

60. Spierenburg (2001, p. 96).

61. Cf. Trotha (1997, pp. 15, 20ff.).

62. Rummel (1993, p. 88). For an overview of the respective German studies, see Schwerhoff (1999, pp. 112ff.). Furthermore, the programme of a «historical anthropology of violence» postulated by Dinges should be mentioned here once again. Dinges has an understanding of violence similar to Trotha's.

63. For a more detailed analysis cf. Schwerhoff 2003).

64. Spierenburg (1997, p. 10). If the criteria of «physical violence» was to be generalized like this, then the exclusion of certain crimes, above all infanticide, but also rape, would have to be criticised as well. This exclusion, too, originates only from the fact that certain contexts of crimes can be distinguished from one another quite clearly. Thus, Spierenburg (1996, p. 73), notes that infanticide tells us less about violence than about shame and despair.

65. Fuchs (1999, p. 139ff.).

66. Apart from the works of Martin Dinges, the essay by Walz (1992) must be mentioned as a classic analysis of the "agonal» culture; cf. Frank (1995b). It should be pointed out that the 
category 'honour' is used here as a general category of analysis and not, as in Lacour's works, as one type of conflict among many others.

67. Eisner (2001a, p. 92).

68. Cf. Schulze $(1982,1983)$. For the connecting points between the research on crime and the study of protests, see contributions in Häberlein (1999).

69. Kottmann (1998, p. 14).

70. Cf. Dinges (2000).

71. Eibach (1998, p. 381f.).

72. Elias (1997, vol. II., pp. 420 ff.); Spierenburg (2002, p. 101).

73. Cf. Schwerhoff (2000, p. 154f.).

74. Schindler (1992).

75. Schuster (2000a); Häberlein (1998).

76. Schwerhoff (1991, p. 185f.).

77. Frank (1995b, p. 337).

78. Cf. the discussion in Dinges (1989, pp. $425 \mathrm{ff}$.).

79. For a discussion of the paradigm of 'confessionalization' $c f$. Bahlcke, Strohmeyer (1999).

80. For hints of such a change, see Frank (1995a).

81. Eisner (2001b, pp. 91ff.).

\section{ABSTRACTS}

«Violence and the Civilising Process: Does it work?» - a question raised by Pieter Spierenburg in a recent issue of CHS will be the reference point for the following article. In contrast to Spierenburg my answer to this question is: 'No, it does not'. First I comment on the validity of late medieval and early modern 'homicide rates' for the development of a general history of violence. A long-term decline in violence, as it is postulated by Spierenburg, cannot be found in the sources. I will then deal with the role of violence within the theory of civilisation. Norbert Elias' interpretations are based on both a naïve reading of the source material and a simplistic understanding of violence which regards violence as a human 'drive' that needs to be suppressed by social control. In the third and final part of this article I try to develop an alternative explanation of violence which views violence as a meaningful and culturally encoded form of social action. Accordingly, violence should not only be perceived as an object of social control but also as a means of social control.

«Violence et processus de civilisation: est-ce que ça marche?»-Cette question soulevée par Pieter Spierenburg dans un numéro récent de CHS sera le point de départ de cet article. Contrairement à Spierenburg, ma réponse à cette question est: «Non, ça ne marche pas». Dans un premier temps, je commenterai la validité des «taux d'homicides» pour le Moyen-Âge tardif et le début de la période moderne, dans la perspective d'une histoire générale de la violence. On ne peut pas trouver dans les sources le déclin de la violence sur le long terme que postule Spierenburg. Puis je m'intéresserai au rôle de la violence dans la théorie de la civilisation. Les interprétations de Norbert Elias sont basées sur une lecture naïve des sources de compréhension simpliste de la violence, qui voit dans celle-ci une «pulsion» qui doit être réfrénée par le contrôle social. Dans la troisième partie de mon article, j'essaierai de développer une explication alternative de la violence, en tant que forme d'action socialement et culturellement codifiée. En 
conséquence, la violence ne devrait pas être perçue seulement comme un objet mais aussi comme un instrument de contrôle social.

\section{AUTHORS}

\section{GERD SCHWERHOFF}

Technische Universität Dresden, Institut für Geschichte Dresden - Allemagne, gerd.schwerhoff@mailbox.tu-dresden.de 